\title{
Forms of Resistance against the African Postcolony in Brian Chikwava's Harare North
}

\begin{abstract}
The article analyzes the novel Harare North by Zimbabwean diasporic writer Brian Chikwava in the context of African writing of post-independence disillusionment and the Cameroonian thinker's Achille Mbembe's analysis of the African postcolony. Mbembe argues that the inhabitants of the postcolony are alienated not only from the state, but also from their own selves, since the postcolony forces them to adapt to permanent change by creating unstable, fragmented identities. Taking its cue from Mbembe, the study explores the forms of political resistance after the break-down of the subject, in whom the identities of victim and oppressor fluidly co-exist. The study concludes by relating Chikwava's representation of the postcolonial subject to Homi Bhabha's unhomeliness.
\end{abstract}

Key words

Zimbabwean literature; resistance in literature; African diasporic writing; Achille Mbembe; Brian Chikwava; Homi Bhabha

\section{Africa and authenticity}

The influential Cameroonian critic Achille Mbembe opens his book On the Postcolony (2001) by noting how difficult it is to speak about Africa as a real, authentic place. This is because of all the prejudices held against it for centuries. One of these he calls the "negative interpretation": "Africa is never seen as possessing things and attributes properly part of "human nature" (1). The other is the assumption that the African "belongs, up to a point, to a world we cannot penetrate. At bottom, he/she is familiar to us. We can give an account of him/her in the same way we can understand the psychic life of the beast. [...] Africa is essentially, for us, an object of experimentation" (2). 
The function of this othering was of course to both solidify Western identity as a dialectical opposite of Africa and to justify colonization. The act of colonial governance drew upon a prior act of linguistic and conceptual violence in which the native was situated as not just wholly other but as bestial and uncivilized. This was then used in various guises to justify acts of expropriation. Colonial governmentality situated itself in direct opposition to the liberal notions of right, thus revealing the essential void of those notions in the first place.

In this sense, like James Ferguson, V.Y. Mudimbe, Chinua Achebe, and others, Mbembe interprets Africa not as a defined, isolated place but as a fraught relation between itself and the rest of the world which plays out simultaneously on political, psychic, semiotic, and sexual levels. He argues that academic and popular discourse on Africa is still caught within a variety of clichés tied to Western fantasies and fears as reflected, for example, in Joseph Conrad's Heart of Darkness. Africa is seen by the West as

a headless figure threatened with madness and quite innocent of any notion of center, hierarchy, or stability [...] a vast dark cave where every benchmark and distinction come together in total confusion, and the rifts of a tragic and unhappy human history stand revealed: a mixture of the half-created and the incomplete $[\ldots]$ in short, a bottomless abyss where everything is noise, yawning gap, and primordial chaos (3).

Following Fanon and Freud, Mbembe holds that this depiction is not a reflection of a real Africa but an unconscious projection tied to guilt, disavowal, and the compulsion to repeat. "More than any other region, Africa thus stands out as the supreme receptacle of the West's obsession with, and circular discourse about, the facts of 'absence,' 'lack,' and 'non-being,' of identity and difference, of negativeness-in short, of nothingness" (4). This, for Mbembe, is the key for explaining the character of the African postcolony, which has inherited both Western discourses about Africa and colonial modes of governance based on excessive accumulation of material wealth, violence, and voiding the subjects. Its corruption, madness, cannibalistic destruction of its own citizens, excess, and vulgarity reflect this legacy most clearly.

\section{The postcolony in African fiction}

Mbembe's book builds on the work of Fanon in whose eyes the African bourgeoisie could never lead the independent African society towards democracy and prosperity. This is because, as Fanon writes in "The Pitfalls of National Consciousness", the African nationalist middle class aimed to secure for itself all that had been excluded from it under the colonial system. Therefore, Fanon foresaw that triumphant nationalism would inevitably turn against the popular masses in whose name it had campaigned, betraying their cause in the interest of neo-colonial class consolidation. 
The disillusionment with independence became a pervasive theme in the African novel as soon as it became apparent across Africa that independence was not the beginning of self-rule; instead, it was the continuation of colonialism through corrupt arrangements between African governments and global capitalism. Ghanaian writer Ayi Kwei Armah summed it up succinctly in 1969: "The African ruling classes do not rule in the interests of African people. If they function at all, they function as agents of white power" (Armah 1969: 40).

Armah's work is typical of African fiction of the post-independence decades that created imaginative resistance to the betrayals of the revolution and the corrupted humanity of the African nationalist bourgeoisie. For Neil Lazarus, Armah's message is ultimately optimistic. Analyzing his first novel, The Beautyful Ones Are Not Yet Born (1968), Lazarus focuses on the ending, where the protagonist's

dogged refusal to abandon either his principles or his dream of a better society is able to emerge as a potent source of value in the novel. [...] "The man" learns that it is only by continuing his struggle, by resolutely opposing the pull of the degraded reality all around him, and by holding fast to a vision of future social transformation, that he is able to invest his life with a constructive purpose. $[\ldots]$ "[T] he man's" unyielding and heroically brave resistance to the dominative aspects of an unpalatable reality [...] elects to live for the "beautyful ones" of the future. (Lazarus 1990: 78-79)

Similarly, Wole Soyinka has described Armah's novels as ultimately positive, committed to the view of postcolonial subjects as active historical agents with a humanistic desire for "a unifying, harmonizing ideal of a distinctive humanity" (Soyinka 1976: 87). Armah's characters are radical intellectuals struggling to change neocolonialist society, because they identify with it and want "to live within one's society and not beyond it" (Lazarus 1976: 78). In other words, they recognize their individual responsibility for their society's development and see themselves as agents of change. The same can be said of other classic postcolonial African novels of the 1960s to 1980s, such as Chinua Achebe's No Longer at Ease (1960), Ngugi wa Thiong'o's A Grain of Wheat (1967) and Devil on the Cross (1982), or Nuruddin Farah's Close Sesame (1983). Despite the general bleakness, humanity eventually triumphs; there is always hope, heroism, vision and purpose.

This optimism about the possibility of social transformation seems to be wanting in much of post-millennial African fiction. By this I mean especially the literature written by diasporic African authors and published in the West which today constitutes the representative African literature that receives global attention. Its feeling of resignation about social change seems to be a symptom of the times and characterizes the work of both eminent and emerging African authors such as Nigeria's Chika Unigwe, Chris Abani and Helon Habila, Zimbabwe's NoViolet Bulawayo, Tendai Huchu and Brian Chikwava, or the recent work of Ngugi wa Thiong'o and his son Mukoma Ngugi, all of whom live either in Europe or the USA. Their 
characters have lost not only hope, but also their integrity and identity. Having no historical agency, they typically leave Africa for the West, where they exist under false names and invented identities. For instance, in Mukoma Ngugi's short story "How Kamau wa Mwangi Escaped into Exile" (2008), the Kenyan middle-class protagonist dresses up as a Maasai - an "authentic" African - so that he can escape his country more easily. The story's focus on African identity as performance is exemplary of recent African fiction. Since a unified, authentic narrative point of view becomes increasingly difficult to construct in this situation, experimental narrative strategies are often adopted: highly subjective, decentred, anti-linear and often unreliable narration that constantly subverts its own discourse; multiple narrators or multiplicity of points of view; fragmented space and time; the use of absurdity, satire, and the grotesque as key discursive devices; in general, a use of language that destabilizes meaning, leading to a perpetual slippage in signification. While this might create an impression of nihilistic abandonment of any belief in meaning and African historical agency, these postmodern aesthetics in fact constitute a form of resistance against fixed, totalizing images of Africa and objectifying points of view that have dominated traditional Western thinking about Africa and African nationalisms. By establishing African identity as ambiguous, hybrid and performative, they subvert the idea of a single national culture or an African identity, instead presenting Africa as multi-faceted, dynamic, and fragmented.

\section{Mbembe's postcolony}

Mbembe'analysis of the African postcolony offers a useful pathway into the shift African fiction has undergone since the post-independence era. According to Mbembe, the postcolony denies personhood to its subjects through state ideology of normative identities and censorship on expressions of individuality. In addition, it oppresses its citizens by creating a permanent atmosphere of fear, improvisation, discontinuity, surreality, absurdity and simulacra: "The postcolony is characterized by a distinctive style of political improvisation, by a tendency to excess and lack of proportion, as well as by distinctive ways identities are multiplied, transformed, and put into circulation" (102).

The permanent insecurity leads the citizens to form fragmented and provisional identities that are able to internalize a register of improvisations and multiple changes of speed in both mental and material movement. This means that the inhabitants of the postcolony are alienated not only from the state, but from their own selves. How can this kind of de-centred, split subject fight against totalitarian power?

According to Mbembe, to account for both the mind-set and the effectiveness of postcolonial relations of power, we need to go beyond the binary categories used in standard interpretations of domination, such as resistance vs. passivity, autonomy vs. subjection, state vs. civil society, hegemony vs. counter-hegemony, totalization vs. detotalization. These oppositions cloud our understanding of postcolonial relationship which is 
not primarily a relationship of resistance or of collaboration but can best be characterized as convivial, a relationship fraught by the fact of the commandement [Mbembe's term for state power] and its "subjects" having to share the same living space. Precisely this logic - the necessary familiarity and domesticity in the relationship - explains why there has not been (as might be expected from those so dominated) the resistance or the accommodation, the disengagement or the "refusal to be captured"[...]. Instead, this logic has resulted in the mutual "zombification" of both the dominant and those apparently dominated. (104)

In other words, Africans are accomplices in the grotesque autocracies which too often preside over their destinies and which dominate them not only through coercion but also through complex patterns of words and behaviour which can extend to the most intimate activities. If the colony was focused on making the citizens more productive, the postcolony is intent on disciplining their bodies (Mbembe 2001: 114). The dramatization of power in the postcolony becomes obscene, through public executions in which the crowd watches and applauds. The postcolony's "grotesque art of representation, its taste for the theatrical, and its violent pursuit of wrongdoing to the point of shamelessness" (115), is according to Mbembe, part of the postcolonial semiotics of power.

Mbembe takes his inspiration from Bakhtin, who maintains that obscenity and the grotesque are modes of resistance against power by turning it into an object of ridicule. All of this takes a different form in the context of the African postcolony characterized by "conviviality, even connivance" (Mbembe 128) - meaning that ordinary people guide, deceive, and toy with power instead of confronting it directly:

In the postcolony, an intimate tyranny links the rulers with the ruled-just as obscenity is only another aspect of munificence, and vulgarity a normal condition of state power. If subjection appears more intense than it might be, this is because the subjects of the commandement have internalized authoritarian epistemology to the point where they reproduce it themselves in all the minor circumstances of daily life-social networks, cults and secret societies, culinary practices, leisure activities, modes of consumption, styles of dress, rhetorical devices, and the whole political economy of the body.

(128, emphasis mine)

The "postcolonized subject" thus acts in a self-contradictory way that both undermines and affirms power (129). According to Mbembe, "The real inversion takes place when, in their desire for a certain majesty, the masses join in the madness and clothe themselves in cheap imitations of power to reproduce its epistemology [...]. It is precisely the situations of powerlessness that are the situations of violence par excellence" (133). 


\section{Brian Chikwava, Harare North}

All of the above issues can be identified in the debut novel Harare North (2009) by Brian Chikwava, Zimbabwean prize-winning writer who left his country after the economic collapse of 2001 and has since been living in London. Echoing Mbembe's analysis of Africa as a symbol of "negativity" or "nothingness", Chikwava says: "The Zimbabwe I knew no longer exists. The book will be published there but no one will buy it. No one buys books now. They are no longer a priority" (Laing 2009). The society Chikwava knew had literally disappeared, remaining only on the level of memory and desire. As one of his characters says, "Zimbabwe was a state of mind, not a country" (183).

Chikwava's novel has been analyzed in the context of migration, asylum seekers, Zimbabwean diaspora, alienation, heterotopia and the idea of home (see, e.g., Ndlovu 2010; Noxolo 2014; Manase 2014; McCann 2014; Wicomb 2015); however, no attention has yet been given to its many connections with Mbembe's theorization of the African postcolony. These include the representation of Africa as a void or absence, a place of non-being; the multiple, ambiguous and fluid identities of Africans who have inherited corrupt forms of power; the conviviality of the victims with the oppressors and the resulting "zombification" of both; the obscenity and grotesque character of power; and the ludic character of resistance.

\section{Fear, improvisation, simulacrum}

Narrated by an un-named narrator in broken English, the novel from the beginning problematizes the notion of identity as stable and the binary pair of victim/ oppressor. The protagonist arrives to London claiming to be a victim of Robert Mugabe's government that has been widely known for human rights violations: "Me I tell them I have been harass by them boys in dark glasses because I am youth member of the opposition party" (4). However he soon informs the reader of being a Mugabe supporter and a member of the Green Bombers, Mugabe's military youth brigade persecuting dissidents. By constantly changing his identity, the protagonist both resists and flirts with power, making him Mbembe's "homo ludens par excellence" (104). He declares his genuine belief in the necessity of violence to eliminate the "enemies of the state" (8) for the sake of the nationalist cause. His child-like straightforwardness makes him not so much an unreliable as a morally alienating narrator, even though he is one of the former victims of the postcolony who joins the militia as a survival strategy:

If you is back home leading rubbish life and ZANU-PF party offer you job in they youth movement to give you chance to change your life and put big purpose in your life, you don't just sniff at it and walk away when no one else want to give you graft in the country even if you is prepared to become tea boy. (17) 
Becoming a member of the Green Bombers, loyal to the ruling ZANU-PF party, the protagonist turns from being a victim to an oppressor. Repeating the slogans of the ruling party, he participates in the official ideology which has been called by Terence Ranger "patriotic history": "Me I know heaps of history." (19). As Mbembe argues, "in a colony, one function of language is to distort everything. To exist, separately and together, colonizer and colonized distort whatever comes to hand, anything. Indiscriminately, they assign a burden of fiction to places, events, people, to everything and nothing" (179-180). In Harare North, history is distorted to justify violent repossessions of white farms by war veterans. No distinction is made between $19^{\text {th }}$-century colonization and $20^{\text {th }}$-century land politics, including post-independence land reform: "How do you say you buy land that was never sold by no one in the first place unless you like buying things that have been thief from someone?" (19) Even though this process, known as "the fast-track land redistribution", led to the collapse of the nation's economy, it was officially represented as the glorious final act of decolonization.

Due to the narrator's skewed sense of reality, an effective reading of the novel must necessarily rely on extra-textual knowledge of Zimbabwean post-independence history. This includes Robert Mugabe's on-going political violence against ethnic minorities, white farmers and opposition voters that culminated in the cynically-named Operation Murambatsvina (Operation Drive Out Rubbish) of 2005. This large-scale government campaign to forcibly clear Zimbabwe's slum areas displaced over 700,000 people. Officially represented as a crackdown against illegal housing and commercial activities, the campaign in reality aimed to punish those who voted for the opposition. Zimbabwean government has thus been repeating the tyrannical colonial practices by forcibly resettling its own citizens, who become internal exiles. Such practices are justified by ideas such as "progress" or "order". The protagonist of Chikwava's novel understands the covert reasons for this violence (which the government is not very concerned to hide) and sides with the government: "Me I don't have no sympathy for Zimbabwean people about this because they have spend a lot of time throwing they tails all over and trying to vote for opposition party" (204).

In light of the traditional spiritual bond between the Shona and the land where their ancestors are buried, such removals lead to the discontinuity of family identities, breakdown of social networks and national cohesiveness: "And then me I hear that people in the village where Mother is buried will be moved somewhere because government want to take over the area since emeralds have now been discovered there" (17). The protagonist clearly sees the connection between Mugabe's terrorisation of his own citizens and colonial politics: "This village, Mother's family have been there since 1974 when they was moved from fertile land in Mazoe because the land have been given as reward to some British Second World War veteran. Now they have to move again?" (74). Nevertheless, he dismisses the story as propaganda against the state: "I don't want to hear no more of this propaganda. I have read everything and I know what to believe" (119). Ironically, while the government no longer hides its intentions, it is the citizen 
who distorts the truth. According to Mbembe, the simulacrum (le simulacre) "becomes the dominant modality of transactions between the state and society, or between rulers and those who are supposed to obey" (129). It is a play in which both sides pretend, as it allows the people "to glue back together their fragmented identities. By taking over the signs and language of officialdom, they have been able to remythologize their conceptual universe" (111).

\section{The voided, multiple and split identities of the postcolonial subject}

Set in Brixton, London's multicultural suburb particularly known for its African population, in 2005, the novel centres on a community of Zimbabwean immigrants, many of them illegal, whose numbers increased greatly after Zimbabwe's economic collapse following the violent expropriations of white farms in 2001-2002. Despite their good command of English and relatively good educational background in comparison to other African immigrants (see Ndlovu), they are forced to squat and do illegal unskilled labour as they wait for the approval of their asylum applications. Displaced and having their existence unrecognized by the British society, they exist in a void, becoming non-persons. A parallel can thus be seen between the ways African subjects are voided in Zimbabwe and in London. Yet, they playfully subvert this denial of their personhood by taking advantage of their marginal position. Tsitsi, a young mother, "rents out" her baby to other African immigrants to facilitate their applications for council housing. Shingi, the only character with legal work permit, lends his passport to other Zimbabweans, taking advantage of the difficulty white British administrators experience in distinguishing black Africans on a photograph. In the meanwhile, Shingi dreams of a better future with a French passport, so that he could seduce English girls by pretending to be a Frenchman. The joke is taken up by others who now call him Mr. Chirac: "I...I am not original n-native now," Chirac tells us [...]. "W...we is not the same anymore, Aleck. While yo...you graft hard in Harare North, me I will soon be hitting French wine and wiping my bottom with them butter croissants" (54). As Mbembe writes, "Subjects in the postcolony also have to have marked ability to manage not just a single identity, but several-flexible enough to negotiate as and when necessary" (104). Asylum seekers reinvent themselves in London not only to survive materially, as undocumented migrants, but also for psychological survival - to maintain an image of success that earns social status back home. It seems that what matters is not to "make it" in London, but to make the best illusion of having made it and to have a good story to tell back home: "Maybe when you get home you can tell big story about life in Harare North; big story about how you can become labourer, sewage drain cleaner and then French president; being many people in one person" (53). Another Zimbabwean homeless man claims that "he is American with many degrees; one in psychology, another in science, computers, crime, the climate - just about everything" (128). "He have reinvent himself complete; you will never think he is Zimbabwean if you don't know him" (127). 
Another of the Brixton characters, Aleck, has made up a story about being a shop manager but in reality works as a "BBC" - which stands here for "British Bottom Cleaners" - workers in care homes, a job open even to unapproved asylum seekers. British life and institutions are constantly juxtaposed to the real life of African immigrants and vulgar humor is the only way for the characters to cope with the huge inequalities between their own status and the London middle class. Their unfulfilled dream is to become famous and penetrate among the rich Londoners. This colonial thinking that situates London as an epistemological and ontological centre reveals the simulacrum of the postcolonial margins: a postcolonial subject can become "real", his existence finally recognized, only through an invented narrative, which becomes more "authentic" than the actual lived life:

My big wish is that maybe when we have find good pen driver he can write cat-and-mouse adventure story about us, make us heaps of money, and maybe for just one night before I fly back home, we can afford a chance to stick our noses in at one of them cocktail bars in the city [...] and maybe if the book really sell like them hot cakes, maybe we end up rubbing noses with the mighty people in London. (146)

\section{Conviviality with power in the postcolony}

However, Chikwava's characters are not portrayed as victims of the Mugabe regime or British immigration policy but instead as active agents who are participants in the very same oppressive regimes. Living in intimate conviviality with power, it is the people themselves who create the postcolony. The postcolonial subject is no longer unified - he is split and de-centred: on the one hand, he is running away from the postcolonial state; on the other, he is replicating the corruption of that state. The duplicitous Aleck exploits his Zimbabwean compatriots by charging them rent for living in a squat. In addition, Aleck has impregnated a teenage girl, Tsitsi, and denies it. Behaving like a tyrannical dictator, Aleck criticizes Zimbabwe's president whom he imitates: "Mugabe is evil dictator, it's always the case with them African presidents; they don't know when to leave power" (123). A similarly exploitative attitude is demonstrated by the protagonist, who is initially taken under the wing of his London cousin. After witnessing his cousin's wife having illicit sex with a lover, he blackmails her into regularly giving him money. This process of "mutual 'zombification' of both the dominant and those apparently dominated" (Mbembe 2001: 104) leaves all characters eventually "impotent", as Mbembe argues: Aleck is revealed to work as a "BBC" and loses his face, Sekai loses her superiority over the protagonist and becomes deeply depressed, while the protagonist loses all of his potential allies through his ego-centric behaviour and eventually also his mind.

Hiding his identity as a Mugabe supporter in front of both immigration officers and the Zimbabwean expatriate community, the protagonist lives a double iden- 
tity. The void at the centre of his identity, created by the irreconcilable contradictions between Mugabe's official ideology and the empirical reality, is filled up by the protagonist's identification with Shingi, his childhood friend, depicted by him in heroic proportions as "Comrade Shingi, the Original Native" (9). When Shingi gets beaten up unconscious in street violence in Brixton, the protagonist steals Shingi's clothes, passport, work permit and mobile phone, adopting his identity. He sends comical messages to Shingi's family in Shingi's name claiming to have become a member of the British Parliament, creating a false narrative for Shingi. The postcolonial subject, devoid of meaning, is endowed with meaning through the narrative of success as a British subject - a highly problematic narrative from a postcolonial perspective, yet one that reveals the postcolonial subject's ability to always adapt to a particular situation by changing his persona as a necessary survival strategy. While the protagonist is initially in possession of a double identity - his own and Shingi's - the story ends with him being fully split between his own self and his alter-ego, Shingi, who lies in a coma:

Shingi's trousers is missing now, I am only in his underpants. Right in front of my feeties there is puddle of water that has form from the rain and street lamp is shining into it. I look down in the puddle; the crack that is screaming out of the corner of my glasses' left lens in all directions make things unclear; I can see Shingi looking straight back. (229)

Suddenly, the narrative voice switches into second person singular, alienating itself from the protagonist:

Half-naked, you turn left into Electric Avenue and walk. You start to hear in tongues; it feel like Shingi is on his way back to life. You can tell, you know it; Shingi is now coming back. Already there's struggle over your feeties; you are telling right foot to go in one direction and he is telling left foot to go in another direction. You tell the right foot to go in one direction and he is being traitor shoe-doctor and tell left foot to go in another direction. You stand there in mental backstreets and one big battle rage even if you have no more ginger for it. (229-230)

This identity splitting at the very conclusion of the novel shows that the protagonist's ludic engagement with multiple identities turns against himself as he no longer knows who he is, losing any touch with reality. His ontological identity crisis is emphasized as he walks through London with his open suitcase on his head, losing everything from it, even the stolen passport and all of his money. $\mathrm{He}$ thus symbolically returns to his initially vacant identity: "I put the suitcase down on the pavement to check again what have happen; it's full of nothing" (228). The scene confirms the nothingness at the centre of his identity. The protagonist, like his double Shingi, who is left lying unconscious with his identity stolen, repre- 
sents the brutalized postcolonial subject who never had any identity in the first place - he was just a number to be exploited and violated.

\section{The aesthetics of vulgarity}

How, if at all, could Harare North be described as a socially engaged novel? With its morally alienating narrator, the ambiguity and fluidity of the identity of victims and oppressors, the characters' intimacy with power, and the subversion of values such as community and national identity, the novel undermines the conventional categories of resistance or trauma writing. In their conviviality with power, the characters are not in a position to oppose it. It also self-reflexively undermines the very idea of fighting state violence with literature: "Look at history, my friend. The path of many of us is set by few fat bellies with sharp horns and hard hoofs; they gore and trample you the moment they know you see through they cloud of jazz numbers. And you want me to fight them with poems?" (181-182)

According to Mbembe, the identity of the "'postcolonized subject' is not necessarily found in acts of 'opposition' or 'resistance' to the commandement," but in his ability to "engage in practices that are fundamentally ambiguous, fluid, and modifiable" (129). Mbembe offers the examples of masses participating in rituals confirming the power of a tyrant while in the next moment "this body breaks into laughter", draining the officialdom of meaning (ibid.). This is amply demonstrated in Harare North, which indulges in naturalistic, obscene humor related to defecation, sex, and bodily fluids, creating grotesque parodies of power. In particular, it is the Zimbabwean dictator whose face is symbolically covered with the faeces of his subjects in a country that has run out of all basic necessities including the toilet paper, as inadvertently imagined by the protagonist:

To the right of the station entrance one newspaper vendor stand beside pile of copies of Evening Standard. On front page of every one of them papers President Robert Mugabe's face is folded in two. I can still identify His Excellency. The paper say that Zimbabwe have run out of toilet paper. That make me imagine how after many times of bum wiping with the ruthless and patriotic Herald newspaper, everyone's troubled buttock holes get vex and now turn into likkle red knots. (1)

This "aesthetics of vulgarity" (Mbembe) derives from the association between the tyrant and self-indulgent, lecherous living - hence the focus in political satire on (over)eating, (in)digestion, and defecation. "The obesity of men in power, their impressive physique or, more crudely, the flow of shit from such a physique - all these appeal to people who can enjoy themselves with mockery and laughter, and, sometimes, even join in the feast" (Mbembe 107). Since almost all of the characters in the novel imitate the role of the tyrant in one way or another, flirting 
with power, this scatological humor is directed as much at them as at the absent Zimbabwean dictator:

"They say Aleck actually work as BBC in Croydon."

"Kak kak kak kak," Shingi let rip as dive onto bed and bury his face into our pillows.

"Aleck picking old people's kaka off beds and then coming here walking around like he is district administrator coming every time to collect tax money even when we have nothing. Harare North is funny place..." (118)

When the protagonist chances upon his cousin's wife and her lover in flagrante, the situation is described with obscene connotations of the body and bodily functions:

There is sweat beads on his forehead. He have three long hairs sticking out of his nose, pointing in random directions. Sekai come out of the toilet and Yakov is relieved. [...] I look inside lounge, I notice that there has been some big feast, with heaps of food on lounge table. [...] Poor Paul, he don't know that he is pounding front bum that have already been thief by this pointy-headed Rasputin. (102-103)

According to Mbembe, "the body is the principal locale of the idioms and fantasies used in depicting power" (107). Festivities and celebrations are the vehicles for giving expression to and displaying the magnificence of power; the body, therefore, is first of all "a body that eats and drinks, and second a body that is open - in both ways: hence the significance given to orifices, and the central part they play in people's political humor" (ibid.). Overeating, indulgence in sex, defecation, all of these bodily functions are described by Chikwava in relation to those with ambitions (or illusions) of power and relished with laughter. The protagonist secretly enjoys the situation, mocking the illicit lovers; afterwards, he joins in the feast, eating leftover food. He thus " become[s] part of a system of signs that the commandement leaves, like tracks, as it passes, and so make[s] it possible to follow the trail of violence" (Mbembe 107).

To a large extent, Mbembe explains, the outbursts of ribaldry and derision are actually taking the official world seriously, at face value. The question of whether humor in the postcolony is an expression of "resistance" or not, whether it is, a priori, opposition, or simply manifestation of hostility toward authority, is for Mbembe of secondary importance. "What gives rise to conflict is not the frequent references to the genital organs of those in power, but rather the way individuals, by their laughter, kidnap power and force it, as if by accident, to examine its own vulgarity" (Mbembe 109). 


\section{Africa vs. Britain}

However, Harare North ridicules not only the Zimbabwean postcolony and its representatives and collaborators, but also Britain, parodying British consumerist lifestyle and mass culture. "British culture" is revealed to be consumer culture of brand names: "We talk heaps about how we now have to start getting familiar with them clothes labels if we want to acquire proper culture" (147). Even alternative cultures such as animal rights activism have become part of mainstream and succumb to mass hysteria, losing touch with reality. When the squat dwellers find a rat in their kitchen, "Jenny has spin him some number about animal rights and why we should learn to live with the rat" (169).

It might be tempting to read the novel as being about the clash between African tradition and Western modernity. While the Africans use the mobile and the internet, they simultaneously participate in traditional spirituality - such as conducting umbuyso ceremony for the departed - and believe in witchcraft and sorcery. One of the female characters, MaiMusindo, sources her authority and power in the community from her reputation as a sorceress, or "Nyamutambanengwena" (110): "I can lift my dress up and show you things that will give you bad luck for the rest of your life if you want to try me" (110). Superstition and belief in magic is however present among the British underclass as well, as seen in the flyer distributed by one of the British squatters:

\section{Professor of All Psychics, Master Visionary \& Inventor}

Do you have problem with: immigration, love, cheating, abuse, relationships, infidelity, stubborn children, health, keeping the one you love happy, finding a job, money? Specialising in cleansing and purification, palm and chakra readings. Call me for results today, tomorrow may be too late! (194)

At the same time, being poor, lost and devoid of identity is not restricted to immigrants, and being British does not necessarily equal money, status and "authenticity". Rather, these categories are shown to be unstable and fluid:

Like them immigrants that spend time mixing rhythm and politics under the chestnut tree outside the Ritzy Cinema, Jenny and Dave is also failures in life. They is the first poor white folk that I ever get to know [...] Like them immigrants they also have them asylum-seeker eyes; them eyes with the shine that come about only because of a reptile kind of life, that life surviving big mutilation in the big city and living inside them holes. (2)

The novel subverts colonial discourse about Africa also through its representation of London. While Zimbabwe is figured in the narrative as a void, a place devoid of meaning, London is similarly stripped of signification. Already the novel's title, Harare North, merges London with Harare, placing the protagonist into an unreal, illusory space of dreams and desires. The colonial image of London 
as a world metropolis and former imperial center never appears in the novel; instead, the narrative largely takes place in the immigrant suburb of Brixton with its impoverished and vagrant population, African market-stall sellers offering exotic foods such as yams and salted fish, "street vendors, skunk dealers, incense vendors, Tube ticket touts, homeless people and thiefs" (139). The rest of London is unintelligible to the displaced protagonist, who cannot decode its signs and signifying practices, such as pub names, commercial labels, social conventions, or newspaper stories: "There's them names like King's Head, The King's Arms, the Queen's Head and things like that; evidence of them murdered kings and queens everywhere" (10). While this obviously points to the way cultural meanings are only available to those who are part of the signifying systems in which those meanings are produced, it also breaks down the opposition between the postcolony and the former colonial metropolis. The novel's resistance, then, is found precisely in these places where Africa and Europe collide and deconstruct each other, showing the old paradigms to be meaningless.

\section{Conclusion: the unhomely}

A few words remain to be said about one of the central metaphors in the story the derelict Brixton house occupied by the African squatters. When he first sees it, the protagonist describes it as looking like his friend Shingi:

It have two roof top windows that have red brick arch. That make the windows look like big sad eyes. Below them sad eyes is one large bay window that stick out like nose. When I look at the nose, the eyes and black parapet wall - this is Shingi straight and square. (29)

For the orphaned, displaced protagonist, it is his childhood friend Shingi, the subject of his happiest memories, who embodies the idea of "home" to him. However, he betrays both this idea of home and his friendship when he seeks to get rid of Shingi once he is no longer useful to him. Soon afterwards, he steals Shingi's identity, symbolically getting "inside his head." Shingi, however, lies in hospital in a coma, and his "head" is a place without signification. The squat, which is both a battle-ground for its inhabitants and a constant potential target of invasion by the police, other Zimbabwean immigrants or vagrants, can be read as metonymically figuring both Zimbabwe and Britain as no-places, i.e., places empty of a moral order and meaning. As it turns out, the characters' escape from oppression to Britain is illusory, since they continue to oppress each other in London, significantly titled Harare North, as if they had never left Zimbabwe.

In one of the final, almost apocalyptic scenes, the protagonist destroys the house when feverishly looking for a rat: 
I start to rip them kitchen-floor skirting out with claw hammer. Then the floorboards; [...] I see them dusty and PVC pipes. [...] I don't know what time it is, but it is way after midnight when the prepay electricity meter run out of credit and suddenly there is darkness inside Shingi's head. [...] I don't know how long I work, removing them floorboards, but soon time stop [...]. I don't go out until this graft is done. I sleep and wake up sweating because I have been having nightmares about rat eating all my money. (217)

The destroyed, abandoned house offers to be read as an example of Homi Bhabha's "unhomeliness." According to Bhabha the state of the "unhomely" is not a state of lacking a home, or the opposite of having a home; it is rather the creeping recognition that the line between the world and the home is breaking down. As Bhabha puts it: "In that displacement the border between home and world becomes confused; and, uncannily, the private and the public become part of each other, forcing upon us a vision that is as divided as it is disorienting" (141). The unhomely for Bhabha is the result of repression and trauma related to the "wider disjunctions of political existence" (144). Chikwava's protagonist's trauma is his experience of economic collapse in Zimbabwe at the turn of the millennium, when money was symbolically eaten up by the catastrophic hyperinflation, but he represses the self-evident truth that those responsible for this were members of Robert Mugabe's government. For Bhabha the unhomely is expressed in the sensation that your home is not yours, and he broadens Freud's discussion of the Unheimlich from personal to political causes. Bhabha's unhomely appears through "holes" in the fabric of reality, things that remained unsaid, questions that remained unanswered, a place "where the relation of 'object' to identity is always split and doubled" at the edge of the knowable (145). In Harare North, the protagonist must leave the house that became his dwelling for the past months, because he is afraid of being hunted down by Shingi's relatives. Like Zimbabwe, Britain offers him no safe refuge because of his split identity that cannot accept the reality around him. He thus remains both literally and symbolically homeless, as emphasized by the empty suitcase on his head. He represents the unsettled postcolonial subject who reminds us of the violence with which nations are constructed. Revealing the nation as fiction, it is no longer possible for Chikwava to write a novel in the line of Ayi Kwei Armah that would offer any individual resistance, personal responsibility or hope, since no identification with the nation is possible. If there is any resistance potential in Chikwava's novel, it is in its refusal of the nation, since it has proved to be destructive for the people. By focusing on these "freak displacements" (Bhabha 1992: 146), Bhabha suggests, we could start writing a new history of world literature that would centre on transnational histories of migrants, refugees and the colonized, because they constitute the site of exchange between self and other, public and private, breaking down the categories on which the violence of the postcolony is based. 


\section{References}

Achebe, Chinua (1977) “An Image of Africa: Racism in Conrad's Heart of Darkness." Massachusetts Review 18: 782-794.

Achebe, Chinua (1960) No Longer at Ease. London: Heinemann.

Armah, Ayi Kwei (1968) The Beautyful Ones Are Not Yet Born. London: Heinemann.

Armah, Ayi Kwei (1969) "Fanon: The Awakener." Negro Digest 18 (12): 4-9, 29-43.

Bhabha, Homi (1992) "The World and the Home." Social Text No. 31/32: 141-153.

Chikwava, Brian (2009) Harare North. London: Jonathan Cape.

Fanon, Frantz (1965) "Pitfalls of National Consciousness." In: The Wretched of the Earth. Trans. Constance Farrington. London: MacGibbon and Kee.

Farah, Nuruddin (1983) Close Sesame. London: Allison \& Busby.

Ferguson, James (1999) Expectations of Modernity: Myths and Meanings of Urban Life on the Zambian Copperbelt. Berkeley: University of California Press.

Laing, Olivia (2009) "The book will be published in Zimbabwe ... no one will buy it." The Guardian, January 4, 2009. Available at <http://www.theguardian.com/books/2009/jan/04/hotlistbooks-fiction-brian-chikwava> [accessed May 1, 2015].

Lazarus, Neil (1990) Resistance in Postcolonial African Fiction. New Haven and London: Yale University Press.

Manase, Irikidzayi (2014) "Representations of the Post-2000 Zimbabwean Economic Migrancy in Petina Gappah's An Elegy for Easterly and Brian Chikwava's Harare North." Journal of Black Studies 45(1): 59-76.

Mbembe, Achille (2001) On the Postcolony. Berkeley - Los Angeles - London: University of California Press.

McCann, Fiona (2014) "Uncommonly Other in Belfast, London and Harare: AlieNation in Robert McLiam Wilson's Ripley Bogle and Brian Chikwava's Harare North." Commonwealth Essays and Studies 37(1): 67-78.

Mudimbe, V. Y. (1988) The Invention of Africa: Gnosis, Philosophy, and the Order of Knowledge. Bloomington: Indiana University Press.

Ndlovu, Thabisani (2010) "Where Is My Home? Rethinking person, family, ethnicity and home under increased transnational migration by Zimbabweans." African Identities 8(2): 117-130.

Ngugi, Mukoma (2008). "How Kamau wa Mwangi Escaped into Exile.” Wasafiri 54 (Summer): $57-62$.

Ngugi, wa Thiong'o (1967) A Grain of Wheat. London: Heinemann.

Ngugi, wa Thiong'o (1982) Devil on the Cross. London: Heinemann.

Noxolo, Patricia (2014) "Towards an Embodied Securityscape: Brian Chikwava's Harare North and the asylum seeking body as site of articulation." Social \& Cultural Geography 15(3): 291312.

Ranger, Terence (2005) "Rule by Historiography: the struggle over the past in contemporary Zimbabwe." In: Muponde, Robert and Ranka Primorac (eds.) Versions of Zimbabwe: New Approaches to Literature and Culture. Harare: Weaver Press, 217-243.

Soyinka, Wole (1976) Myth, Literature and the African World. Cambridge: Cambridge University Press.

Wicomb, Zoë (2015) "Heterotopia and Placelessness in Brian Chikwava's Harare North." In: Palladino, Mariangella and John Miller (eds.) The Globalization of Space: Foucault and Heterotopia. Abdingdon and New York: Routledge, 49-64. 
Dobrota Pucherová is a researcher at Institute of World Literature, Slovak Academy of Sciences. Her work focuses on African and Afro-European postcolonial literature in English, especially in relation to theories of nationalism, migration and diaspora, cosmopolitism, modernity, resistance and social engagement. She is also interested in postcolonial theorizations of East-Central Europe. Her latest book is titled Postcolonial Europe? Essays on Post-Communist Literatures and Cultures (co-edited with Róbert Gáfrik; Brill, 2015).

Address: Dr. Dobrota Pucherová, Ústav svetovej literatúry, Slovenská akadémia vied, Konventná 13,81103 Bratislava, Slovakia. [email: dobrota.pucherova@savba.sk] 
